\title{
LITHOFACIES RECOGNITION BASED ON FUZZY LOGIC AND NEURAL NETWORKS: A METHODOLOGICAL COMPARISON
}

\author{
Talita Lammoglia, Julio Kosaka de Oliveira and Carlos Roberto Souza Filho
}

\begin{abstract}
Fuzzy logic and neural networks methods are commonly applied in various areas of the petroleum industry. In this work, both methods are used comparatively to lithofacies prediction in wells. The input dataset available for the study includes 4 known well logs (gamma ray, neutronic porosity, Density and Sonic) and lithologic description of cores for 14 wells drilled in the Namorado oil field. This field is located in the Campos Basin (SE Brazil) and its reservoir rocks are composed of sandstone turbidites. Core descriptions correspond to 3,196 samples of facies distributed in irregularly spaced intervals of 14 wells. Among the samples, 21 different facies were recognized by the geologists. These lithofacies were regrouped into three representative lithofacies: sandstone, shale and limestone. Fuzzy logic and backpropagation neural network models were produced using data from three key wells. Each model was applied to all other 11 wells. The comparison was individually performed between the original core intervals and the synthetic lithofacies column. Results revealed that for the original 3,196 facies samples, 2,353 were correctly recognized by the fuzzy logic method, whereas 2,599 were correctly predicted by neural networks. These correspond to approximately $73 \%$ and $83 \%$ accuracy, respectively. The neural networks method also exhibited enhanced results for each well separately. In summary, both methods performed well in recognizing three main lithofacies intervals for 14 wells at the Namorado Field. The analysis indicates that the methods showed good performance in the recognition of lithofacies for all wells investigated in the Namorado oil field. In general, neural networks showed a product with accuracy around $10 \%$ higher than that obtained by fuzzy logic. The accuracy yielded by neural networks is also higher when wells are compared individually. The superiority of the results obtained with neural networks suggests better ability of this algorithm on the recognition of lithofacies, particularly in geologic scenarios similar to those approached here.
\end{abstract}

Keywords: lithofacies, fuzzy logic, neural networks.

RESUMO. Lógica fuzzy e redes neurais são métodos comumente aplicados em diversas áreas da indústria do petróleo. Nesse trabalho, ambos são utilizados comparativamente para reconhecimento de litofácies em poços. Os dados disponíveis para o estudo incluem 4 perfis derivados de medidas indiretas nos poços (raios gama, porosidade neutrônica, densidade e sônico) e descrição litológica de testemunhos para 14 poços perfurados no Campo de Namorado. Esse campo situa-se na Bacia de Campos (SE do Brasil) e compreende arenitos turbidíticos como rocha reservatório. A descrição de testemunhos foi feita em 3.196 diferentes pontos distribuídos irregularmente ao longo dos testemunhos. Dentre as descrições, 21 fácies foram reconhecidas pelos geólogos, as quais foram aqui reagrupadas em três grupos principais: folhelho, arenito e calcário. Os modelos de treinamento por redes neurais e lógica fuzzy para ambos os algoritmos foram gerados com base em 3 poços contendo seções-tipo. Os modelos foram aplicados para predição de litofácies nos outros 11 poços. Na sequência, as litofácies preditas foram comparadas com as descrições de testemunhos. Os resultados mostram que dentre as 3.196 descrições, 2.353 e 2.599 foram corretamente reconhecidas por lógica fuzzy e redes neurais, respectivamente, ou seja, atingiram $73 \%$ e 83\% de similaridade com as descrições dos geólogos. A análise indica que os métodos apresentaram bom desempenho no reconhecimento de litofácies para todos os poços abordados no Campo de Namorado. No geral, as redes neurais apresentaram um produto com acurácia em torno de 10\% superior aquele obtido por lógica fuzzy. A porcentagem de acerto das redes neurais é superior também quando os poços são comparados individualmente. A superioridade dos resultados obtidos com redes neurais sugere melhor habilidade deste algoritmo no reconhecimento de litofácies, particularmente para cenários geologicamente similares ao aqui estudado.

Palavras-chave: litofácies, lógica fuzzy, redes neurais.

Department of Geology and Natural Resources, Geosciences Institute, Universidade de Campinas, Rua Pandiá Calógeras, 51, Mail Box 6152, 13083-970 Campinas, SP, Brazil. Phone +55(19) 3521-4535; Fax: +55(19) 3521-4552 - E-mails: talita.lammoglia@ige.unicamp.br; joliveira10@slb.com; beto@ige.unicamp.br 


\section{INTRODUCTION}

Mathematical and computational techniques are widely applied in the oil industry, particularly in petrophysical assessment of reservoirs. Petrophysics comprises the study of physical and chemical rock properties and their interface with fluids, including gaseous and liquid hydrocarbons, and aqueous solutions (Tiab \& Donaldson, 2004). A fundamental aspect of petrophysics is determining and estimating rock properties through well log measurements.

Wireline acquisitions in open holes provide petrophysical data for oil exploration purposes. In these operations, several physicochemical properties of rocks (i.e. rock + fluid) are recorded, such as resistivity, density, porosity, radioactivity, and others. Petrophysical evaluation both of electrical and image profiles allows, for example, to calculate porosity and permeability of rocks, as well as water saturation. This information is essential in the petroleum exploratory chain, since it assists on defining target areas and guiding production of oil fields. Indirect lithologic inference is another important product of well logs interpretation. Lithologies retrieved from petrophysical interpretation are known as lithofacies.

Here, we reflect on the applicability of fuzzy logic and neural networks lithofacies prediction based on four different basic logs. The Namorado oil field in Campos Basin (Rio de Janeiro State, Brazil), was selected for the study. The predictions yielded from each method were intercompared and also evaluated against geological descriptions of boreholes. The notion was to weigh the applicability of these techniques for semi-automatic determination of lithofacies.

The Campos Basin is the largest oil province in operation in Brazil. It is located offshore, along the northern coast of Rio de Janeiro and Espírito Santo States, covering about 100,000 km² (Milani \& Araújo, 2003). Campos is a passive margin style basin related to the breakup of Gondwana in the Early Cretaceous. Its tectonic evolution encompasses rift and post rift supersequences. Rocks and sedimentary sequences in the basin can be grouped into three tectono-sedimentary megasequences, generically known as:

(i) non-marine rift megasequence, which was strongly influenced by rift tectonics;

(ii) the transitional megasequence, during which there was a relative tectonic quiescence and deposition of evaporites;

(iii) marine megasequence deposited in frank marine environment, affected by gravitational tectonics and halokinesis (Angel et al., 1994; Guardado et al., 2000; Winter et al., 2007).
The interconnection of source and post-evaporite reservoirs rocks is related to the rifting tectonics and halokinesis. The main source rocks in the Campos Basin are comprised in the Lagoa Feia sedimentary Formation. Reservoirs are reported in Albian to Miocene siliciclastic turbidite, Barremian coquina, fractured basalts, and in Albian carbonates (Dias et al., 1990; Bruhn et al., 2003).

The Namorado oil field, discovered in 1975, is located in the north-central portion of an oil accumulation trend in the Campos Basin (Fig. 1). The producing reservoir is informally known as Namorado sandstone. It is comprised in the upper part of the Macaé Formation and was deposited during the Albian-Cenomanian (Rangel et al., 1994, Milani \& Araújo, 2003). Namorado sandstones include twelve turbiditic sets, which are amalgamated and divided in two successions of reservoirs separated by a sequence of marls, shales, mudstones and bioturbed calcilutites (Vasquez, 2000).

\section{MATERIALS}

A database consisting of 4 well logs and core description of 14 wells drilled in the Namorado oil field was organized to develop this work. The well logs selected for the project were gammarays (GR), neutron porosity (NPHI), sonic (DT) and bulk density (RHOB). These data were provided by the ANP \& Petrobras under the Namorado Field-School project.

Gamma rays (GR) are electromagnetic waves emitted spontaneously by radioactive elements (e.g. uranium, thorium and potassium) present in rock Formations. It is the natural radioactivity of rocks due to their composition (i.e. paragenesis) and therefore, linked to their depositional environment. Chemically reactive clay-rich surfaces tend to absorb radioactive ions. Thus, clay-rich rocks tend to have higher values of GR. GR logs are commonly used to define lithology, as well as for correlation between wells and shaliness calculation (Schlumberger, 1987; Bassiouni, 1994; Tiab \& Donaldson, 2004).

Neutron Porosity, also known as NPHI, allows investigating porosity by counting thermalized neutrons. The wireline tool performs gamma rays counting as a function of time. The rate of decay is related to the capture of thermal neutrons by the rock Formation and, mostly, the amount of hydrogen atoms. Assuming that most of the hydrogen atoms are associated with water molecules or hydrocarbons (both contained in the pores), it is possible to estimate rock porosity. In short, neutron porosity corresponds to the hydrogen index, which reflects the porosity. Its usage extends to lithological interpretation and detection of zones containing light oil or gas (Brock, 1986; Darlin, 2005; Rose, 2006). 


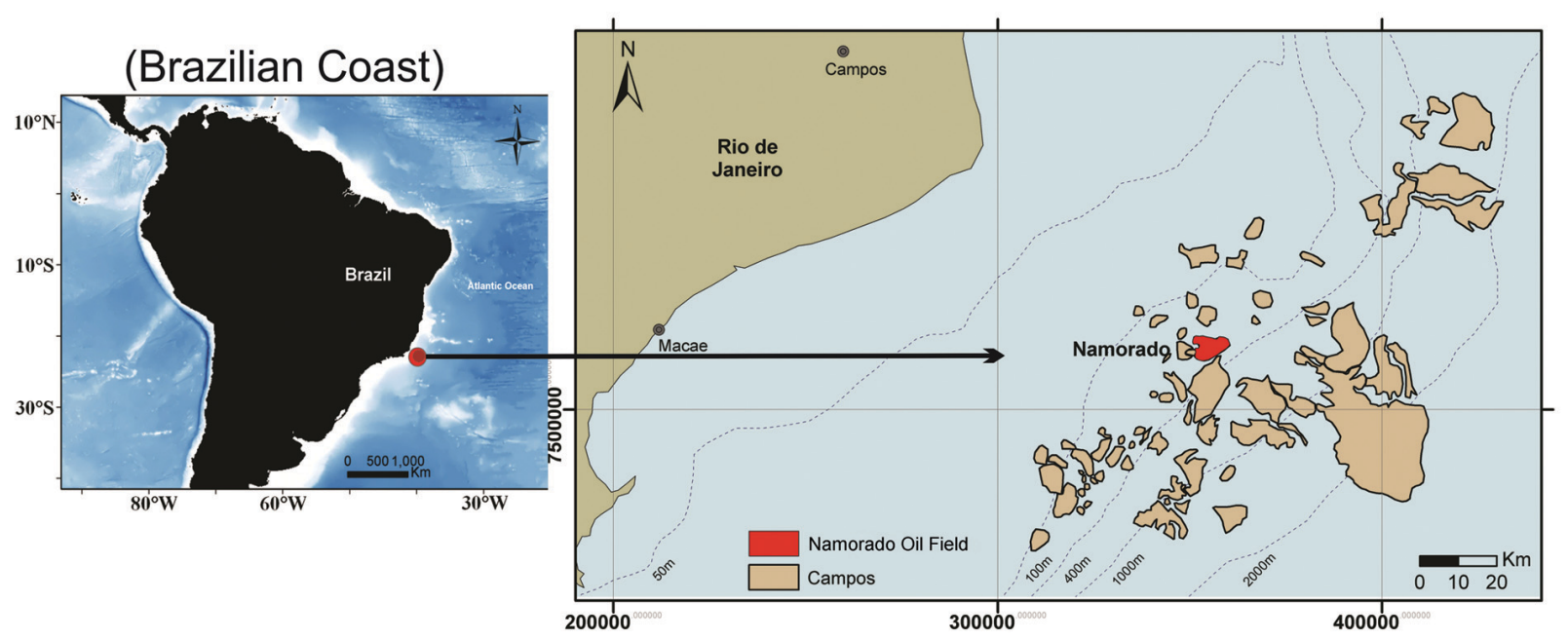

Figure 1 - Study area (based on Milani \& Araújo, 2003).

Sonic logs (DT) mark the time that a sonic pulse takes to traverse a rock interval (Schlumberger, 1987). Therefore, sonic log measures the transit time of a compressional wave through the rocks. This time is related to porosity and lithology (i.e. density and composition). This log is commonly used to determine porosity, and allow well-to-seismic correlations. Sonic values depend on the matrix material, cement, type of fluid that fills the pores, Formation pressure and temperature (Tiab \& Donaldson, 2004). Transit time in water-saturated shales ranges from 58 to $143 \mu \mathrm{s} / \mathrm{ft}$ (Ellis \& Singer, 2008), whereas average values for sandstone and limestone are about 55.5 and $47.5 \mu \mathrm{s} / \mathrm{ft}$, respectively (Bassiouni, 1994).

Density logs indicate bulk density (RHOB), i.e. the average density of one unit of the Formation (rock + fluid) and it is defined as the mass per volume unit of Formation $\left(\mathrm{g} / \mathrm{cm}^{3}\right)$. The profiling tool contains a radioactive source of Cesium-137, which emits high speed gamma rays. These electrons collide with rocks, losing energy (i.e. Compton Effect). After several collisions, gamma rays returning to the profiling tool are registered and counted. Since the number of collisions is related to the number of electrons contained in the rock, the tool allows inferences about rock density. This log is widely used for lithology and porosity estimatives (Whittaker, 1985; Schlumberger, 1987).

\section{METHODS}

In order to assess the applicability of fuzzy logic and neural networks to predict lithofacies, the following steps (Fig. 2) were undertaken here: (i) reorganization of core descriptions yielded in the laboratory; (ii) creation of synthetic facies curves based on core descriptions; (iii) fuzzy logic and neural networks training based on 3 wells and 4 logs (GR, NPHI, RHOB, DT), (iv) data processing by fuzzy logic and by neural networks, (v) assessment of results obtained for 14 wells and validation. The Interactive Petrophysics ${ }^{\top M}$ (Senergy) software was used for fuzzy logic, whereas GeoFrame/Litho Toolkit (Schlumberger) was used for neural networks processing.

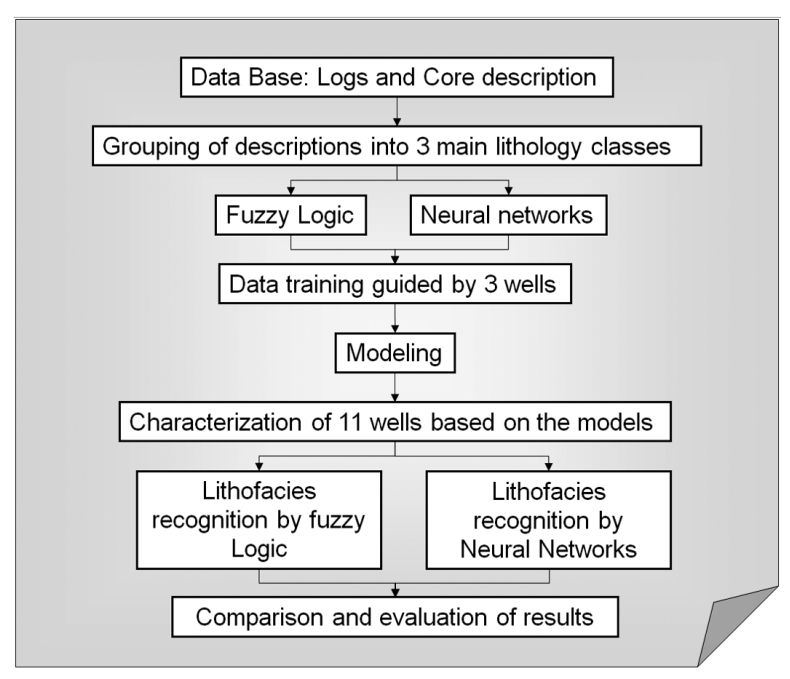

Figure 2 - Project methodology flow chart.

\section{Facies clustering}

Cores were described by Petrobras experts. Descriptions encompass 3196 facies intervals distributed irregularly along 14 wells. Core descriptions include approximately 21 facies. In the present investigation, these descriptions were grouped into three major groups: shale, sandstone and limestone (Table 1). Rhythmites 
Table 1 - Clustering of 21 lithologies yielded from core descriptions into synthetic, representative units of shale, sandstone and limestone.

\begin{tabular}{|c|c|c|}
\hline Shale & Sandstone & Limestone (carbonate) \\
\hline $\begin{array}{c}\text { Interlaminated siltite } \\
\text { and bioturbed shale }\end{array}$ & $\begin{array}{c}\text { Compact or gradational } \\
\text { sanstone }\end{array}$ & Interlaminated \\
\hline Radioactive shale & Cemented sandstone & $\begin{array}{c}\text { Carbonatic conglomerates } \\
\text { and breccias }\end{array}$ \\
\hline Clayly shale & $\begin{array}{c}\text { Interlaminated bioturbed } \\
\text { sandstone }\end{array}$ & Rhythmite \\
\hline $\begin{array}{c}\text { Sandy and clayly diamictite } \\
\text { Shale with layers of } \\
\text { bioturbed marlstone }\end{array}$ & $\begin{array}{c}\text { Cemented sandstone with } \\
\text { Intraclasts or bioturbation }\end{array}$ & - \\
\hline $\begin{array}{c}\text { Interlaminated clayly siltite } \\
\text { and deformed sandstone }\end{array}$ & $\begin{array}{c}\text { Thin interlaminated } \\
\text { sandstone and shale }\end{array}$ & - \\
\hline $\begin{array}{c}\text { Interlaminated clayly siltite } \\
\text { and marlstone }\end{array}$ & $\begin{array}{c}\text { Amalgamated coarse } \\
\text { sandstone }\end{array}$ & - \\
\hline Bioturbated marlstone & Conglomerate & - \\
\hline- & Laminated medium \\
sandstone & - \\
\hline & $\begin{array}{c}\text { Sandstone with } \\
\text { argillaceous intraclasts }\end{array}$ & - \\
\hline
\end{tabular}

and muddy interlaminated were grouped as "carbonate" based on their descriptions. Moreover, their log responses present a combination of low natural radioactivity (gamma ray) with high density (RHOB), which is characteristic of carbonates. Once facies were grouped, core descriptions were used to create a facies log restricted to cored intervals. For comparison and validation, all Petrobras descriptions were assumed as correct, despite the fact that samples were not available for further probation.

\section{Fuzzy logic}

Saggaf \& Nebrija (2003) and Hsieh et al. (2003) used fuzzy logic for geologic applications and lithofacies estimation in particular contexts. A broader discussion of fuzzy logic in geology was provided by DeMicco \& Klir (2004). Here, we used four curves for data training via fuzzy logic: gamma ray (GR), neutron porosity (NPHI), bulk density (RHOB) and sonic (DT) of three wells: 3NA 0001A RJS, 3NA 000 RJS and 3NA 0004 RJS. Initially, statistics were independently calculated for each log of each facies (shale (class 1), sandstone (class 2) or limestone (class 3)) for all training wells. Among all descriptions, 216 points were shale (class 1); 360 sandstone (class 2) and 29 limestone (class 3). Statistics of each log of the three classes are presented in Figures 3,4 and 5 .
The distribution of values for each log and for all three classes can be better assessed with crossplots (Fig. 6).

Based on the training statistics, (see Figs. 3 to 6), a fuzzy model was applied to the other 11 wells. For each well, the probability of each curve fitting each of the three classes (lithofacies) was calculated as follows:

$$
P\left(C_{i}\right)=\sqrt{n_{i} \times e^{-\left(C-\mu_{i}\right)^{2} /\left(2 x \sigma_{i}^{2}\right)}}
$$

where, $P\left(C_{i}\right)=$ probability of curve $C$ belonging to the lithofacies $i, n_{i}=$ number of samples from lithofacies $i, C=$ input value of the $\log , \mu_{i}=$ average value of $\log C$ for the lithofacies $i, \sigma_{i}=$ standard deviation of curve $C$ to class $i$.

The probability sum was then calculated for each depth for each log based on the following equation:

$$
1 / P_{i}=1 / P\left(C 1_{i}\right)+1 / P\left(C 2_{i}\right)+1 / P\left(C 3_{i}\right)+1 / P\left(C 4_{i}\right)
$$

Therefore, the final probability $P_{i}$ or most likely solution was computed. The lithofacies assigned to each interval was, in practice, the class with the highest probability.

\section{Neural networks}

Neural networks are parallel computing systems, distributed and inspired in the human brain. These systems are adaptive and can 


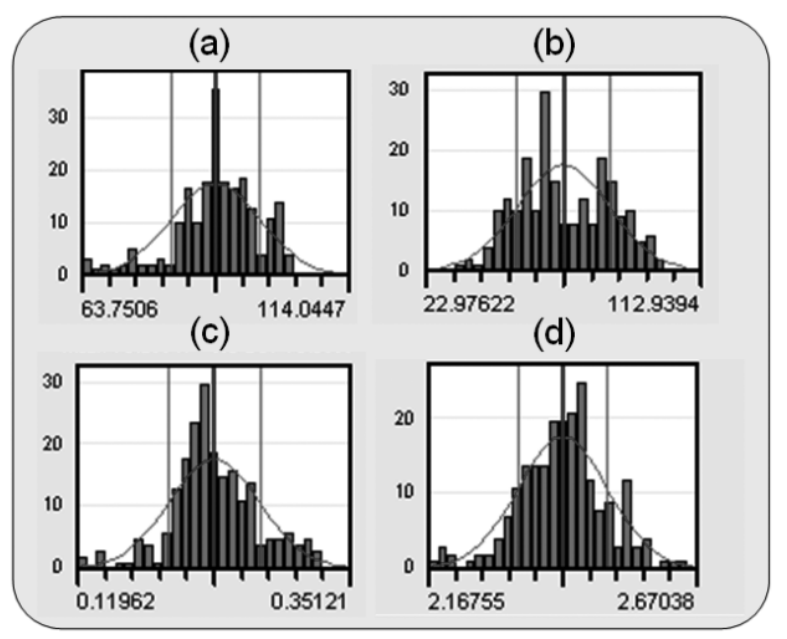

Figure 3 - Histogram of log records for 216 samples classified as shales (a) Sonic $=$ Minimum Value $=63.75 \mu$ s/tt, Maximum Value $=114.05 \mu \mathrm{s} / \mathrm{ft}$, Average $=$ $88.89 \mu \mathrm{s} / \mathrm{tt}$, Standard Deviation = 8.38; (b) Gamma ray $=$ Minimum Value $=22.98 \mathrm{API}$, Maximum Value $=112.94 \mathrm{API}$, Median $=67.96 \mathrm{API}$, Standard Deviation $=$ 14.99; (c) Neutron Porosity (NPH) $=$ Minimum Value $=0.1196 \mathrm{~m}^{3} / \mathrm{m}^{3}$, Maximum Value $=0.3512 \mathrm{~m}^{3} / \mathrm{m}^{3}$, Average $=0.2354 \mathrm{~m}^{3} / \mathrm{m}^{3}$, Standard Deviation $=0.039$; (d) Density $(\mathrm{RHOB})=$ Minimum Value $=2.17 \mathrm{~g} / \mathrm{cm}^{3}$, Maximum Value $=2.67 \mathrm{~g} / \mathrm{cm}^{3}$, Average $=2.42 \mathrm{~g} / \mathrm{cm}^{3}$, Standard deviation $=0.084$.

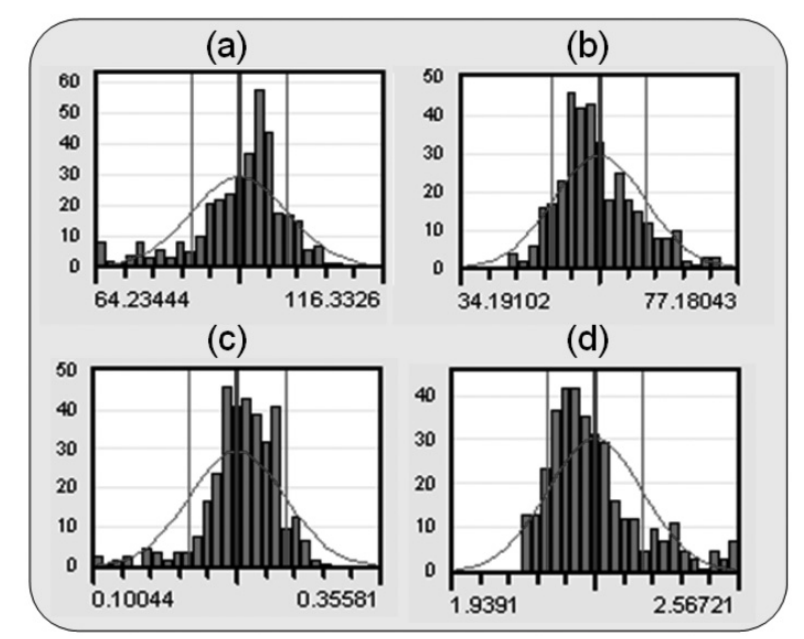

Figure 4 - Histogram of log records for 360 samples classified as sandstone (a) Sonic $=$ Minimum Value $=64.23 \mu \mathrm{s} / \mathrm{ft}$, Maximum Value $=116.33 \mu \mathrm{s} / \mathrm{tt}$, Average $=$ 90.28 $\mu$ s/tt, Standard Deviation = 8.68; (b) Gamma ray = Minimum Value = 34.19 API, Maximum Value =77.18 API, Median = 77.18 API, Standard Deviation $=$ 7.17 ; (c) Neutron Porosity (NPHI) $=$ Minimum Value $=0.1004 \mathrm{~m}^{3} / \mathrm{m}^{3}$, Maximum Value $=0.3558 \mathrm{~m}^{3} / \mathrm{m}^{3}$, Average $=0.2281 \mathrm{~m}^{3} / \mathrm{m}^{3}$, Standard Deviation $=0.042$; (d) Density $(\mathrm{RHOB})=$ Minimum Value $=1.94 \mathrm{~g} / \mathrm{cm}^{3}$, Maximum Value $=2.57 \mathrm{~g} / \mathrm{cm}^{3}$, Average $=2.25 \mathrm{~g} / \mathrm{cm}^{3}$, Standard deviation $=0.104$.

learn or gain knowledge from data by means of artificial intelligence techniques (e.g., Nóbrega \& Souza Filho, 2003). Generally, the network is composed of simple processing units (nodes or neurons). These units are arranged in one or more layers and interconnected by links whose weight is indicative of the connection strength (Hewitson \& Crane, 1994; Brown et al., 2000).

Neural networks are suitable for pattern recognition from datasets because of their (i) ability to extract hidden patterns that can be imperceptible to humans and other traditional statistical techniques; (ii) facility to analyze data without any prior knowl- edge about its distribution; (iii) possibility to work with noisy, limited, interdependent and non-linear data; (iv) performance and speed, particularly when spatial features have complex characteristics and sources comprise different statistical distributions; (v) option to add new data continuously as input layers; (vi) and capability to analyze large data sets (e.g., Hemilson \& Crane, 1994; Brown et al., 2000; Nóbrega \& Souza Filho, 2003).

For this work, the neural network model was obtained by a supervised system, using a training method coined Back Propagation or Backward Propagation of Errors. As the name denotes, 


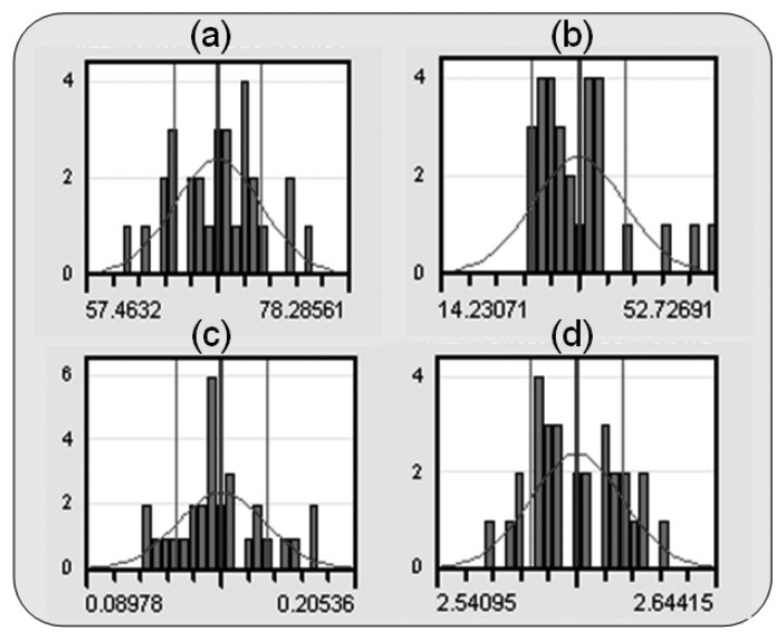

Figure 5 - Histogram of log records for 29 samples classified as limestone (carbonate) (a) Sonic $=$ Minimum Value $=57.46 \mu \mathrm{s} / \mathrm{ft}$, Maximum Value $=78.28 \mu \mathrm{s} / \mathrm{ft}$, Average $=67.87 \mu \mathrm{s} / \mathrm{tt}$, Standard Deviation $=3.47$; (b) Gamma ray $=$ Minimum Value $=14.23 \mathrm{API}$, Maximum Value $=52.73 \mathrm{API}$, Median $=33.48 \mathrm{API}$, Standard Deviation $=6.42$; (c) Neutron Porosity $(\mathrm{NPHI})=$ Minimum Value $=0.0898 \mathrm{~m}^{3} / \mathrm{m}^{3}$, Maximum Value $=0.2054$, Average $=0.1476 \mathrm{~m}^{3} / \mathrm{m}^{3}$, Standard Deviation $=$ 0.0193; (d) Density $(\mathrm{RHOB})=$ Minimum Value $=2.54 \mathrm{~g} / \mathrm{cm}^{3}$, Maximum Value $=2.64 \mathrm{~g} / \mathrm{cm}^{3}$, Average $=2.59 \mathrm{~g} / \mathrm{cm}^{3}$. Standard deviation $=0.017$.

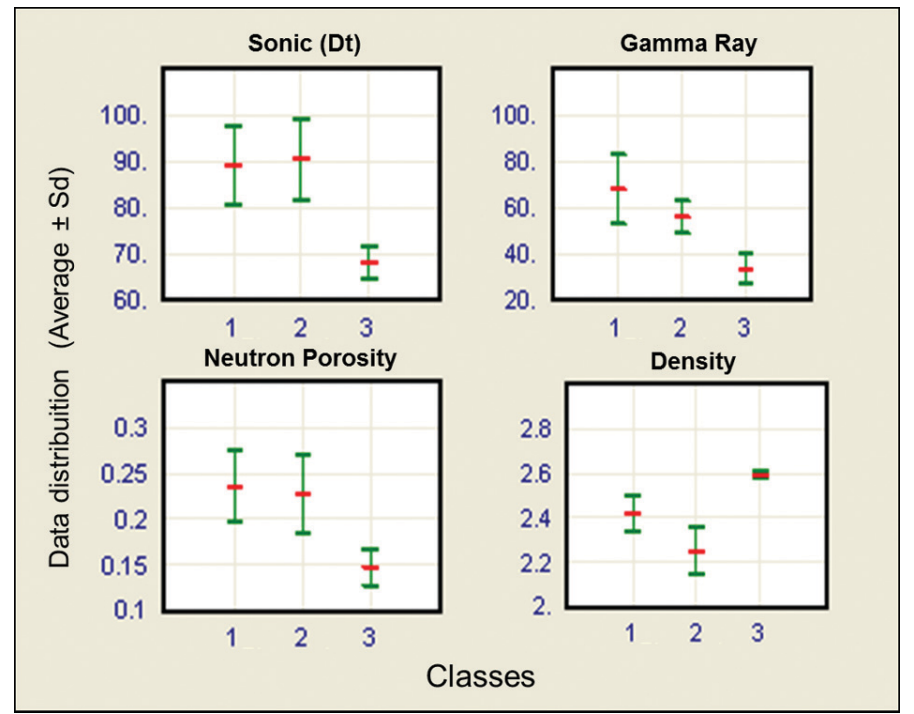

Figure 6 - Crossplots. The upper and lower limits of the green bar indicate the standard deviation and the red dot indicates the average. Class $1=$ shale. Class $2=$ sandstone. Class $3=$ limestone.

in this system the errors propagate backwards from the output to the input nodes. The connection weights are modified during the calculation and while data is propagated throughout the network. The result is always compared to the expected results in order to update the weights. This algorithm uses the gradient descent rule (or delta rule) error for supervised learning. The aim of the algorithm is to minimize function error, defined by the squared sum of errors. Therefore, this method requires the computation of the error function gradient for each iteration (cf. Bryson \& Ho, 1969; Rumelhart et al., 1986; Widrow et al., 1990).
It is possible to train a model with facies input (core descriptions) and logs using a neural network system. During processing, the system recognizes data patterns guided by the selected logs. After training, the model can be applied to other wells in order to recognize lithofacies for each logged depth.

For the neural network approach, wells 3NA 0001A RJS, 3NA 0002 RJS and 3NA 0004 RJS were also used for data training. Processing was based on 100 interactions, 2 hidden layers, $50 \%$ cross-validation (i.e., $50 \%$ of the data used in training was also used for validation) and probability threshold of 0 . Graphs 
presented in Figures 7 and 8 show the quality of the training process. Figure 7 illustrates the learning rate, which is a representation of the difference between the desired output and the current output. It is possible to note that, in the beginning of the training process, the learning rate is higher, indicating that the algorithm is continuously recognizing new patterns. However, after a certain number of iterations, learning tends to stabilize at a certain level and then to decay, which indicates that the algorithm is generating redundant knowledge and the system is saturated. Figure 8 shows that errors obtained with training and validation decrease together, while the network is within learning process. The combined decrease of curves indicate a good quality of training.

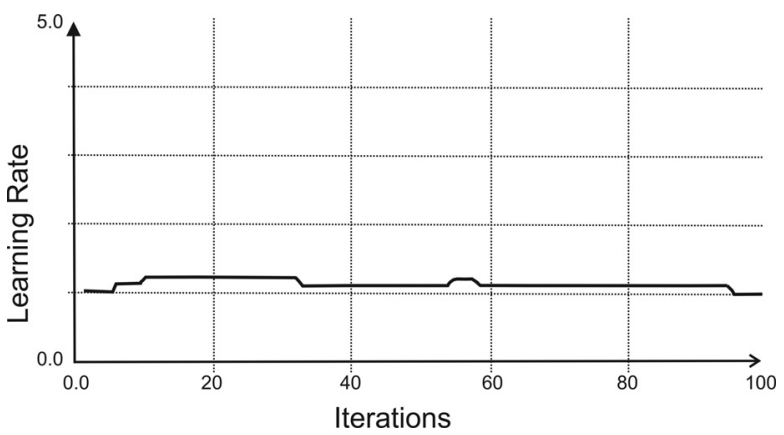

Figure 7 - Neural networks processing: learning rate $v s$. iterations.

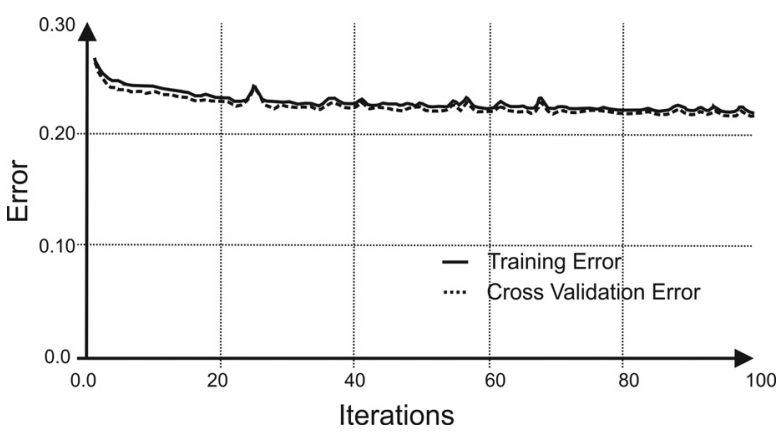

Figure 8 - Cross validation: errors vs. iterations. Error is measured based on a pre-defined value of $50 \%$ (i.e. $50 \%$ of the data used for training will also be used for validation).

\section{RESULTS AND DISCUSSION}

Both methods used for lithofacies estimates proved effective (Figs. 9, 10 and 11, and Table 2).

Results displayed in Table 2 indicate that both methods were able to estimate lithofacies with an average above $70 \%$ of similarity to core descriptions. It is noteworthy that, except for the 7NA 0007 RJS well, the results of neural networks are superior to those obtained by fuzzy logic. The difference between the two algorithms is pronounced when their average similarity to core description are compared. For all 11 wells to which models were applied, a similarity 10\% higher was obtained through neural networks. This dominance may be related to the fact that neural networks also accounts for nonlinear data relationships and trends in behavior among different variables (and not only the numerical value of each input variable). It should be noted that the reduction of the original 21 lithofacies to 3 main classes favored the high percentage of accuracy for facies estimation using both fuzzy logic and neural networks.

Statistics of the logs indicate that density and gamma ray values were highly contrasting among facies. Conversely, sonic log showed a minor variation between shale and sandstone (average 88.89 and $90.29 \mu \mathrm{s} / \mathrm{ft}$, respectively) and higher contrast for limestone (average of $67.87 \mu \mathrm{s} / \mathrm{tt}$ ). A comparable pattern was observed for neutron porosity (average of 0.24 and $0.23 \mathrm{~m}^{3} / \mathrm{m}^{3}$ for shale and sandstone, respectively; and $0.15 \mathrm{~m}^{3} / \mathrm{m}^{3}$ for limestone).

This work presents an evaluation of the effectiveness of lithofacies prediction for turbiditic reservoirs with particular depositional and diagenetic characteristics, under certain degree of compaction and specific fluid characteristics. Such particularities may impose limitations for extrapolation the models to other areas. Besides, variations of instruments and wireline performed by different companies can affect the logs response and, therefore, lithofacies estimation. These differences may require normalization among wells before models are computed.

Facies prediction can be challenging for a database that includes several wells and large depth intervals. Despite the required generalizations, results obtained in this investigation were rather positive and indicate that the methodology can be used on similar case studies. Analogous applications of the methods experimented here can be reached in the absence of core data. In those cases, sidewall cores might be used for training and modeling.

\section{CONCLUSIONS}

Results accomplished in this experiment proved the suitability of neural networks and fuzzy logic algorithms for lithofacies determination based on neutron porosity, sonic, density and gamma ray logs. For both methods, the similarity between lithofacies described by geologists and estimated by the models was above $70 \%$. Fuzzy logic and neural networks showed similarity means of $72.5 \%$ and $82.5 \%$, respectively, proving the later to be more accurate. Therefore, we favor the use of supervised neural networks for lithofacies estimation, particularly to sequences with similar geologic characteristics as those observed in the Namorado oil field. 


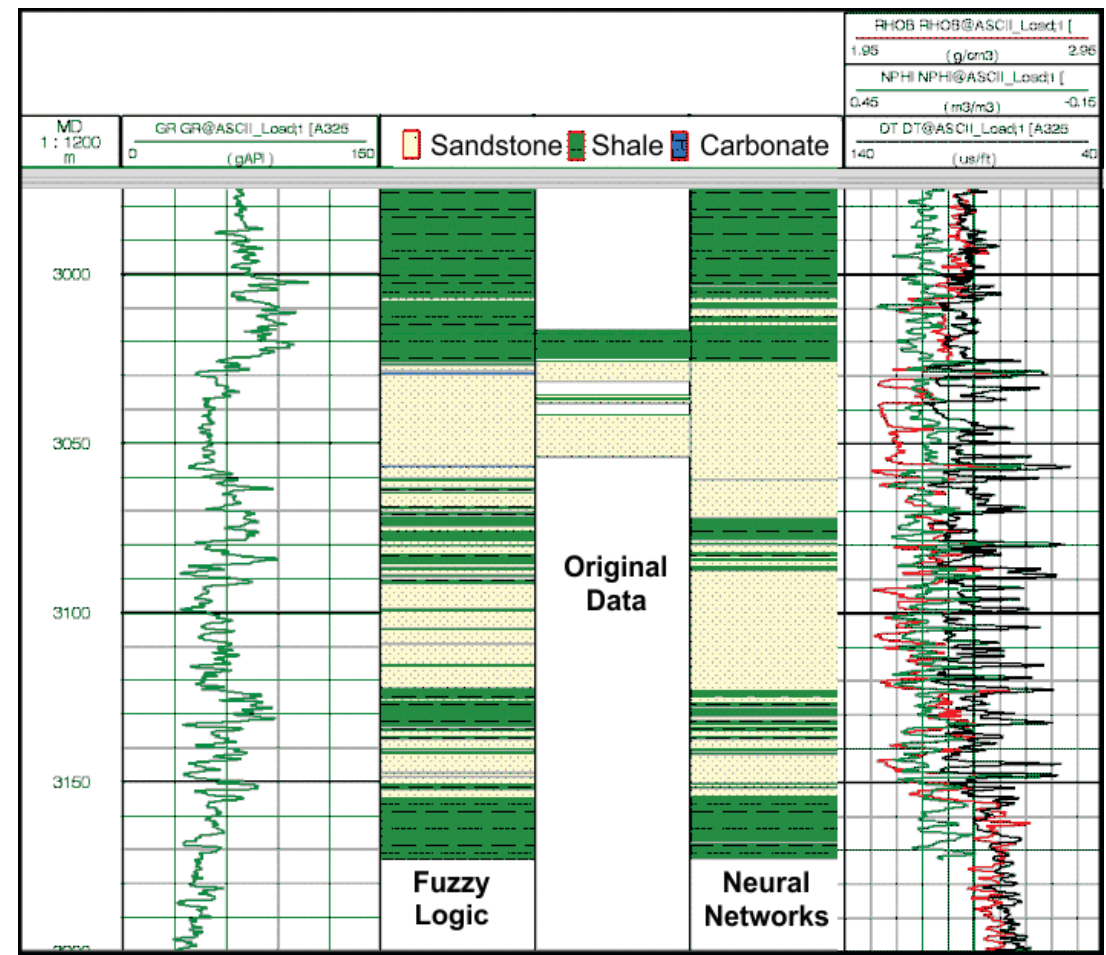

Figure 9 - Well 3NA 0002 RJS used to develop the model/training: 144 intervals described. Fuzzy logic and neural networks depicted $92 \%$ and $97 \%$ of these intervals, respectively.

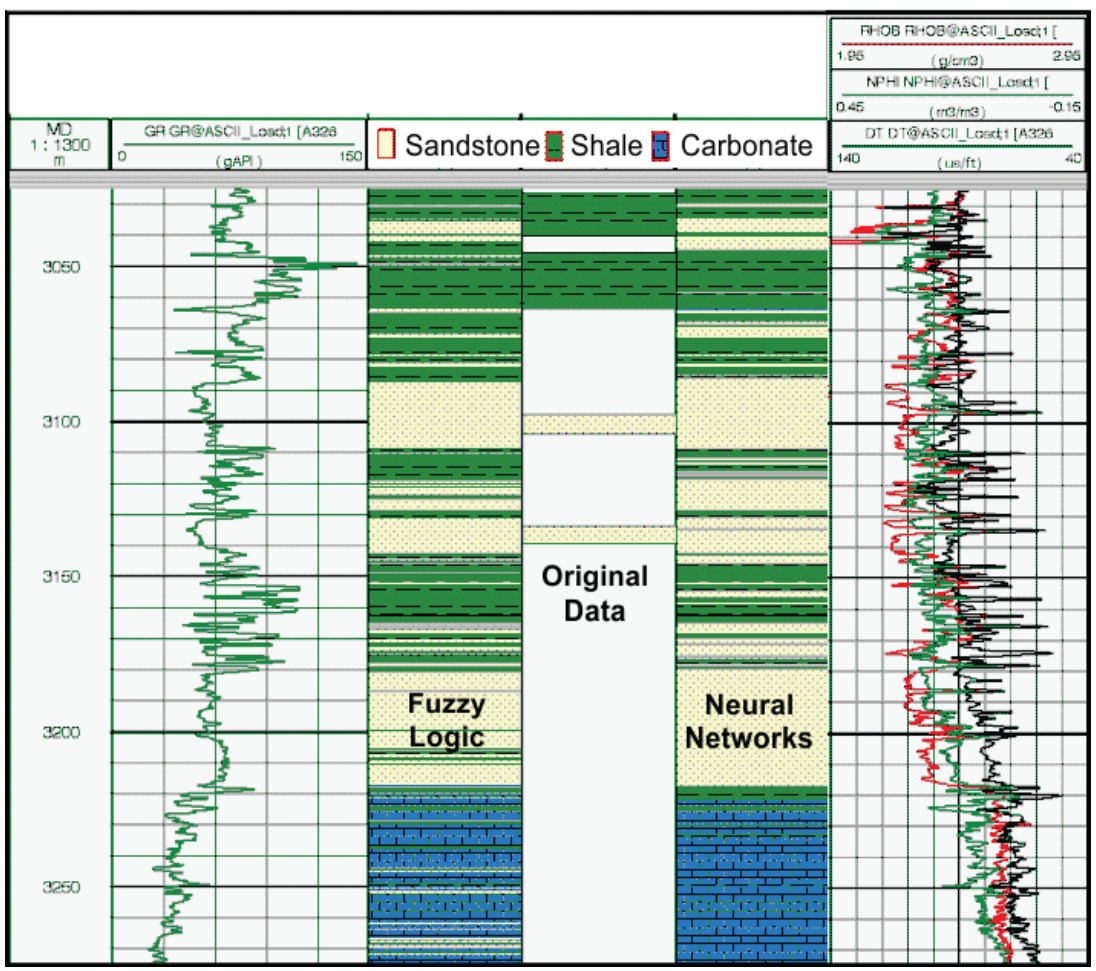

Figure 10 - Well 7NA 0007 RJS used to develop the model/training: 219 intervals described. Fuzzy logic and neural networks recognized $87 \%$ and $85 \%$ of these intervals, respectively. 


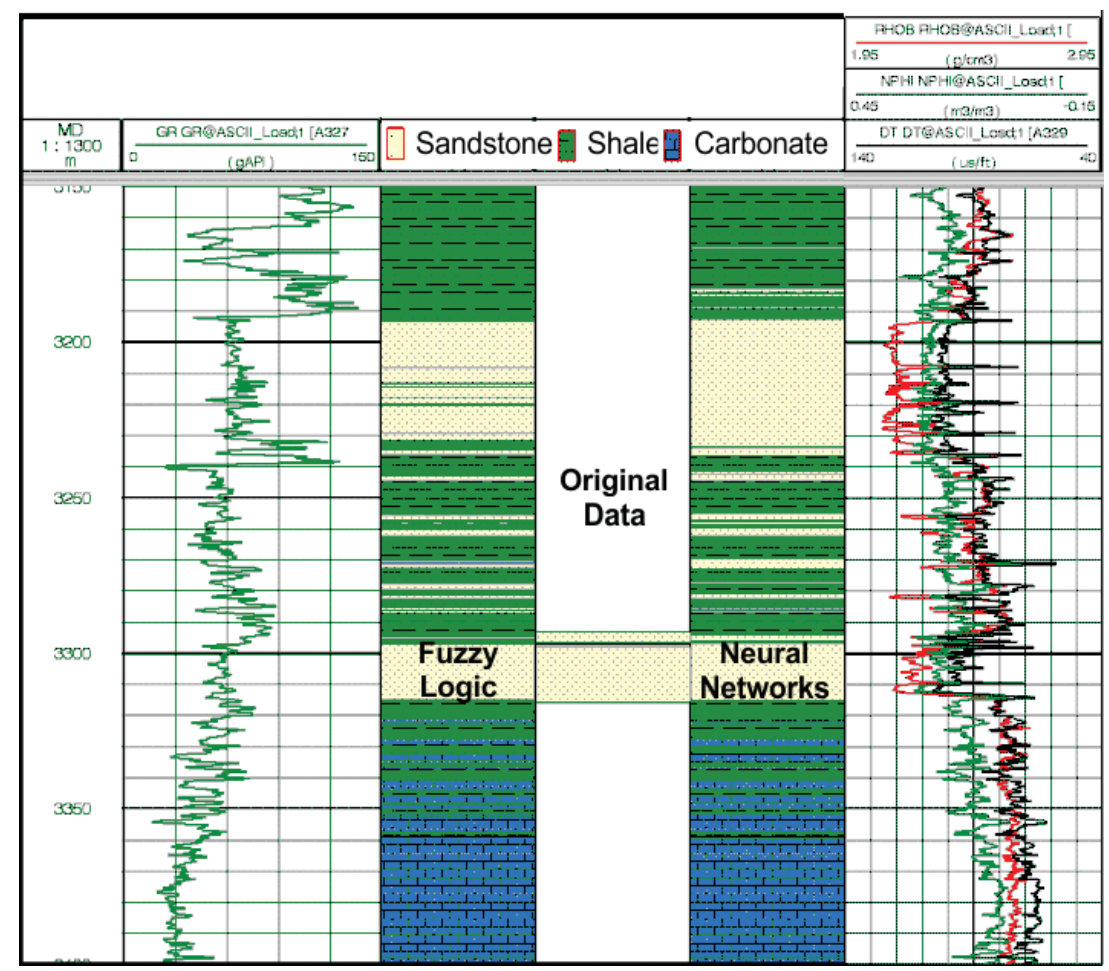

Figure 11 - Well 7NA 0044D RJS used to develop the model/training: 62 intervals described. Fuzzy logic and neural networks depicted $85 \%$ and $98 \%$ of these intervals, respectively.

\section{ACKNOWLEDGMENTS}

We are grateful to Petrobras and ANP for providing the data for the research and to Schlumberger for making the software available for students at the Universidade de Campinas. We also acknowledge the reviewers for their valuable contributions.

\section{REFERENCES}

BASSIOUNI Z. 1994. Theory, Measurement and Interpretation of Well Logs. Richardson, TX. Society of Petroleum Engineers SPE Textbook series vol. 4, $384 \mathrm{pp}$.

BROCK J. 1986. Applied Open-Hole Log Analysis. Contributions in Petroleum Geology \& Engineering. Gulf Publishing Company, Book Division, v.2, $283 \mathrm{pp}$.

BROWN WM, GEDEON TD, GROVES DL \& BARNE RG. 2000. Artificial neural networks: a new method for mineral prospectivity mapping. Aust. J. Earth Sci., 47(4): 757-770.

BRUHN CHL, GOMES JAT, LUCCHESE Jr C \& JOHANN PRS. 2003. Campos Basin: Reservoir Characterization and Management - Historical Overview and Future Challenges. OTC 15220. Offshore Technology Conference held in Houston, Texas, U.S.A., 5-8 May 2003.

BRYSON AE \& HO Y. 1969. Applied Optimal Control: Optimization, Estimation, and Control. Blaisdell Editora, 481 pp.
DARLING T. 2005. Well Logging and Formation Evaluation. Gulf Professional Publishing, Elservier's Science, 326 pp.

DEMICCO RV \& KLIR GJ. 2004. Fuzzy logic in Geology. Elsevier, 347 pp.

DIAS JL, SCARTON JL, ESTEVES FR, CARMINATTI M \& GUARDADO LR. 1990. Aspectos da Evolução Tectono-Sedimentar e a Ocorrência de Hidrocarbonetos na Bacia de Campos. In: GABAGLIA GPR \& MILANI EJ (Eds.). Origem e Evolução de Bacias Sedimentares. Petrobras, p. 333-360.

ELLIS DV \& SINGER JM. 2008. Well Logging for Earth Scientists. Spinger, $2^{\text {nd }}$ ed., $692 \mathrm{pp}$.

GUARDADO LR, SPADINI AR, BRANDÃO JSL \& MELLO MR. 2000. Petroleum system of the Campos Basin. In: MELLO MR \& KATZBJ (eds.) Petroleum systems of South Atlantic margins. AAPG Memoir, 73: 317324.

HEWITSON BC \& CRANE RG. 1994. Neural Nets: Applications in Geography. Kluwer Acad. Publ. Ed., 194 pp.

MILANI EJ \& ARAÚJO LM. 2003. Recursos Minerais Energéticos: Petróleo. In: BIZZI LA, SCHOBBENHAUS C, VIDOTTI RM \& GONÇALVES JH (Eds.). Geologia, Tectônica e Recursos Minerais do Brasil, CPRM, Brasília, BR, p. 541-576.

NÓBREGA RP \& SOUZA FILHO CR. 2003. Análise Espacial Guiada pelos Dados (Data-Driven): 0 uso de Redes Neurais para Avaliação do 
Table 2 - Statistical analysis, including absolute numbers and relative percentages of samples correctly characterized by fuzzy logic and neural networks.

\begin{tabular}{|c|c|c|c|c|c|c|}
\hline & \multirow{2}{*}{ Well } & \multirow{2}{*}{$\begin{array}{c}\text { No. of } \\
\text { samples }\end{array}$} & \multicolumn{2}{|c|}{ Fuzzy Logic } & \multicolumn{2}{|c|}{ Neural Network } \\
\hline & & & no. of samples & $\%$ & no. of samples & $\%$ \\
\hline \multirow{3}{*}{$\begin{array}{l}\text { Input to } \\
\text { Model }\end{array}$} & 3NA 0001A RJS & 163 & 137 & 84 & 143 & 88 \\
\hline & 3NA 0002 RJS & 144 & 133 & 92 & 140 & 97 \\
\hline & 3NA 0004 RJS & 298 & 264 & 89 & 268 & 90 \\
\hline \multirow{11}{*}{ Modeled } & 4RJS 0042 RJS & 131 & 94 & 72 & 111 & 85 \\
\hline & 7NA 0007 RJS & 219 & 191 & 87 & 186 & 85 \\
\hline & 7NA0011ARJS & 735 & 515 & 70 & 576 & 78 \\
\hline & 7NA 0012 RJS & 592 & 443 & 75 & 477 & 81 \\
\hline & 7NA 0037D RJS & 121 & 95 & 78 & 96 & 79 \\
\hline & 7 NA 0040D RJS & 62 & 53 & 85 & 61 & 98 \\
\hline & 7NA 0044D RJS & 110 & 93 & 84 & 99 & 90 \\
\hline & 7NA 0047D RJS & 87 & 71 & 82 & 81 & 93 \\
\hline & 7NA 0048D RJS & 83 & 63 & 76 & 76 & 92 \\
\hline & 7NA 0053D RJS & 196 & 84 & 43 & 132 & 67 \\
\hline & 8NA 0022 RJS & 255 & 117 & 46 & 153 & 60 \\
\hline \multicolumn{2}{|r|}{ Total } & 3196 & 2353 & 1063 & 2599 & 1183 \\
\hline \multicolumn{2}{|r|}{ Average } & & & 75.93 & & 84.50 \\
\hline \multicolumn{2}{|r|}{ Total $^{1}$} & 605 & 534 & 265 & 551 & 275 \\
\hline \multicolumn{2}{|r|}{ Average $^{1}$} & & & 88.33 & & 91.67 \\
\hline \multicolumn{2}{|r|}{ Total $^{2}$} & 2591 & 1819 & 798 & 2048 & 908 \\
\hline \multicolumn{2}{|r|}{ Average $^{2}$} & & & 72.55 & & 82.55 \\
\hline
\end{tabular}

1 - Only wells used to create models / training data. 2 - Wells to which models were applied.

Potencial Poli-Minerálico na região Centro-Leste da Bahia. Rev. Bras. de Geociências, 33(2): 111-120.

PETTIJOHN FJ. 1975. Sedimentary Rocks. Harpercollins, $3^{\text {rd }}$ ed., 628 pp.

ANGEL HD, MARTINS FA, ESTEVES FR \& FEIJÓ FJ. 1994. Bacia de Campos. Boletim de Geociências da Petrobras, 8(1): 203-217.

ROSA H. 2006. Estudo de Caracterização de Eletrofácies por meio de Perfis Geofísicos de Poços e de Amostras de Testemunhos utilizando Estatística Multivariada. Doctorade thesis. Universidade Estadual de Campinas, Instituto de Geociências, Campinas-SP, 230 pp.

RUMELHART DE, HINTON CE \& WILLIAMS RJ. 1986. Learning internal representations by error propagation. In: RUMELHART DE \& MCCLELLAND JL (Eds.). Parallel Distributed Processing, University of San Diego, The MIT Press, Cambridge, MA: M.I.T., 362 pp.

SAGGAF MM \& NEBRIJA EL. 2003. A fuzzy logic approach for the estimation of facies from wire-line logs. AAPG Bulletin, 87(7): 1223-1240.

SCHLUMBERGER. 1987. Log Interpretation - principles/applications. Schlumberger Ltd. N.Y., 198 pp.
TIAB D \& DONALDSON EC. 2004. Petrophysics: Theory and Practice of Measuring Reservoir Rock and Fluid Transport Properties. Gulf Professional Publishing/Elsevier, Oxford, UK, $2^{\text {nd }}$ ed., 889 p.

VASQUEZ GF. 2000. Comportamento viscoelástico do Arenito Namorado e suas relações com atributos faciológicos. Master dissertation, UNICAMP, 214 pp.

WHITTAKER A. 1985. Field Geologist's Training Guide. The EXLOG Series of Petroleum Geology and Engineering Handbooks. IHRDC, EUA, $291 \mathrm{pp}$.

WIDROW B \& LEHR MA. 1990. 30 Years of Adaptive Neural Networks: Perceptron, Madaline, and Backpropagation. Proceedings of the IEEE, 78: $1415-1442$.

WINTER WR, JAHNERT RJ \& FRANÇA AB. 2007. Bacia de Campos. Boletim de Geociências da Petrobras, 15(2): 511-529.

HSIEH B, LEWIS C \& LIN Z. 2005. Lithology identification of aquifers from geophysical well logs and fuzzy logic analysis: Shui-Lin Area, Taiwan. Computers \& Geosciences, 31: 263-275. 


\section{NOTES ABOUT THE AUTHORS}

Talita Lammoglia. Graduated in Geology (UNICAMP, 2006), following an international fellowship at the Institute of Geology of the University of Missouri/Columbia (USA). Holds a Ph.D. in Geosciences (UNICAMP, 2010). Earlier in the career, worked with mineral exploration (Yamana Gold Inc.) and modeling of oil reservoirs (Schlumberger Serviços de Petróleo). Was awarded twice with the Petrobras National Prize on Petroleum Exploration Technology (Undergraduate student-2006/Master student-2008). Received an award as Best Undergraduate Research Work at the XIII Brazilian Symposium of Remote Sensing (Florianópolis, 2007). Since 2008, works for Petróleo Brasileiro S.A. - Petrobras, in the field of applied geology to oil exploration.

Julio Kosaka de Oliveira. Graduated in Geology (Universidade Federal do Rio de Janeiro, 2005). Since then has been working at Schlumberger Oilfield Services. From 2005 to 2009 worked as an expert and provided support for Brazilian users of the Interactive Petrophysics ${ }^{T M}$ and the GeoFrame Geology suites of softwares. Currently works as Techlog Technical Sales and is responsible for its introduction and implementation in Brazil.

Carlos Roberto de Souza Filho. Graduated in Geologic Engineering (Universidade Federal de Ouro Preto, 1988). Holds a Master in Metallogenesis (UNICAMP, 1991) and a Ph.D. in Earth Sciences and Remote Sensing (Open University, England, 1995). His career includes a Young-Research Fellowship (FAPESP-UNICAMP, 1995-1997), an Assistant-Professorship (UNICAMP, 1997-2002) and Associate-Professorship (UNICAMP, 2002-2008). Currently, is a Full Professor at the Geology and Natural Resources Department of the Geosciences Institute (IG) of UNICAMP and leader of the Geotechnology Research Group. Is also a CNPq Researcher (level $1 \mathrm{~A}$ ) and a Member of the São Paulo Academy of Sciences. Is responsible for several research laboratories, including those related to infrared reflectance and emissivity spectroscopy, remote sensing and digital image processing; GIS and data integration (Spatial Data Modeler - ArCSDM). Is a NASA researcher for the ASTER, Mars-Earth Analogs and HyspIRI programs. Presently contributes with the editorial board of numerous international journals, including the International Journal of Applied Earth Observation and Geoinformation and the Mathematical Geosciences. 